패혈쇼크로 인한 액체감쇠역전회복영상에서의 고강도혈관

\author{
이소영 이진형 김명국 유봉구 \\ 고신대학교복음병원 신경과
}

\title{
Fluid-Attenuated Inversion Recovery Hyperintense Vessels Due to Septic Shock
}

\author{
So-Young Lee, Jin-Hyung Lee, Myeung-Kuk Kim, Bong-Goo Yoo \\ Department of Neurology, Kosin University Gospel Hospital, Busan, Korea
}

\begin{abstract}
Hyperintense vessels on fluid-attenuated inversion recovery magnetic resonance imaging (FLAIR MRI) are commonly observed in acute ischemic stroke, especially when accompanied by large vessel stenosis or occlusion. A 41-year-old man presented with cellulitis and enterocolitis. Despite extensive antibiotic therapy, his condition rapidly deteriorated to septic shock. FLAIR MRI showed hyperintense vessel sign in the bilateral intracranial vessels. Septic shock seems to provoke the development of FLAIR hyperintense vessels.
\end{abstract}

J Neurosonol Neuroimag 201S;10(2):175-177

Key Words: Magnetic resonance imaging; Sepsis; Blood vessels
Received: November 28, 2018 Revised: December 5, 2018 Accepted: December 5, 2018

Address for correspondence: Bong-Goo Yoo

Department of Neurology, Kosin University Gospel Hospital, 262 Gamcheon-ro, Seo-gu, Busan 49267, Korea Tel: $+82-51-990-6461$ Fax: +82-51-990-3077 E-mail:ybg99@naver.com
패혈쇼크에서 뇌 영상의 이상은 자주 관찰되며, Virchow-Robin 공간 주위의 다양한 백질변성(leukoencephalopathy)이 주요 소견으로 알려져 있다. ${ }^{1}$ 액체감쇠역전회복 (fluid attenuated inversion recovery, FLAIR)에서 바닥핵, 시상, 속섬유막(internal capsule), 중뇌, 소뇌에서 고신호강 도를 보일 수도 있다. ${ }^{2}$

FLAIR 자기공명영상에서 관찰되는 고강도혈관(hyperintense vessels)은 급성 뇌경색증에서 주로 연구되었고, 큰 뇌 동맥의 폐색으로 인한 혈류가 느려질 때 관찰된다. ${ }^{3}$ 뇌동맥 폐 색에서 역방향과 순방향의 곁순환을 통한 혈류와도 연관되어 있다. ${ }^{4}$

본 증례는 패혈쇼크에서 촬영한 뇌 자기공명영상에서 광범 위한 FLAIR 고강도혈관을 관찰하였기에 문헌고찰과 함께 이 를 보고하고자 한다.

\section{증 례}

41세 남성이 10 일 전부터 발생한 양측 다리와 발의 부종과 통증, 설사 때문에 내원하였다. 과거력에서 당뇨병, 만성 췌 장염, 심장판막증이 있었고, 매일 술을 마시는 상태였다. 신체
진찰에서 하복부에 압통이 있었고, 양측 아랫다리와 발에 부 종, 오목부종 및 홍반성 병변이 있었다. 내원 당일의 생체징후 는 혈압 $100 / 70 \mathrm{mmHg}$, 맥박수 $70 /$ 분, 호흡수 20 회/분, 체 온 $36.6^{\circ} \mathrm{C}$ 였다. 일반혈액검사에서 백혈구 $9,800 / \mathrm{mm}^{3}$, 고민 감 $\mathrm{C}$-반응단백질은 $3.4 \mathrm{mg} / \mathrm{dL}$ 로 증가되었다. 혈청 프로칼 시토닌(procalcitonin)은 $0.145 \mathrm{ng} / \mathrm{mL}$ (정상치 $0.00-0.05$ ) 로 상승되어 있었다. 혈색소 $8.9 \mathrm{~g} / \mathrm{dL}$, 혈소판 $75,000 / \mu \mathrm{L}$ 였 으며, 혈청 알부민 $1.7 \mathrm{~g} / \mathrm{dL}$, 혈액요소질소 $4.6 \mathrm{mg} / \mathrm{dL}$, 크레 아티닌 $0.41 \mathrm{mg} / \mathrm{dL}$, 나트륨 $134 \mathrm{mEq} / \mathrm{L}$ 였다. 프로트롬빈시 간 INR은 2.3 , 당화혈색소는 $9.0 \%$ 로 증가되었다. 복부 computed tomography $(\mathrm{CT})$ 촬영에서 소장과 상부결장에 점막 밑부종과 복수가 있어, 소장결장염으로 진단하였다. 다리병변 은 정형외과에 의뢰하여 연조직염으로 진단받고 석고붕대와 세균배양을 시행하였다. 소장결장염과 연조직염으로 metronidazole, piperacillin, tazobactam 등을 정맥으로 투여하였 다. 내원 3 일에 열감과 전신상태가 더욱 악화되었다. 생체징후 는 혈압 100/70 mmHg, 맥박수 120/분, 호흡수 30회/분, 체 온 $38.2^{\circ} \mathrm{C}$ 였다. 고열에 대한 일반적인 선별검사는 이상이 없 었고, 혈액배양에서도 배양되는 균이 없었다. 양측 다리의 병 변은 세균배양에서 Staphylococcus haemolyticus가 동정되 어 민감한 항생제 teicoplanin을 투약하였다. 항생제와 항진 


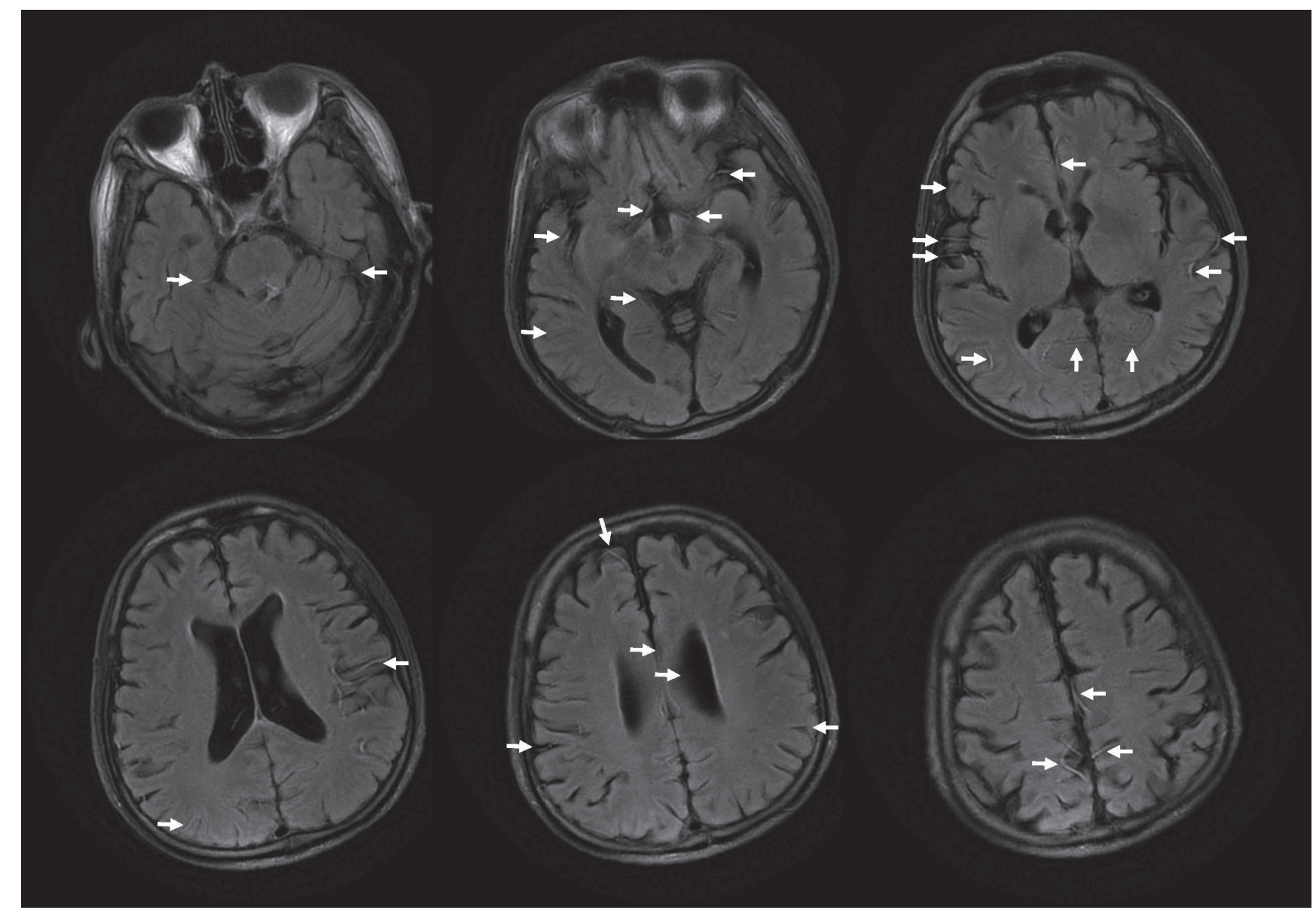

FIG. 1. Brain magnetic resonance imaging showed hyperintense vessel sign (arrows) on fluid-attenuated inversion recovery images.

균제를 투여하였으나, 치료에 반응하지 않고 패혈증으로 진행 하였다. 내원 5 일째에 의식수준의 저하와 함께 혈압이 $70 / 40$ $\mathrm{mmHg}$ 까지 떨어져 패혈쇼크 상태였다. 신경학적 진찰에서는 의식수준은 졸린 상태였고, 시간과 장소에 대한 지남력장애가 있었지만, 뚜렷한 국소 징후는 없었다. 뇌병변을 배제하기 위 하여 자기공명영상을 시행하였고, 짧은 시간 안에 촬영할 수 있는 확산강조영상, FLAIR, 경사기울기영상만을 시행하였다. FLAIR에서 고강도혈관 징후가 천막위와 천막하의 양측에서 관찰되었다(Fig. 1). 침상 옆에서 시행한 경두개도플러에서 모 든 혈관의 박동지수(pulsatile index)는 1.5-1.8 사이로 증가 되었고, 평균 혈류속도는 증가되지 않았다. 좌우측 혈관의 차 이는 없었다. 뇌혈관 상태를 확인하기 위하여 시행한 CT 혈관 조영술은 이상이 없었다(Fig. 2). 혈압은 수액과 혈압상승제 에 의하여 잘 조절되지 않았다. 내원 7일 후 혈액검사에서 백 혈구 $1,710 / \mathrm{mm}^{3}$ 로 저하되었고, 고민감 $\mathrm{C}$-반응단백질은 2.5 $\mathrm{mg} / \mathrm{dL}$, 프로칼시토닌 $5.96 \mathrm{ng} / \mathrm{mL}, \mathrm{D}$-dimer $2.53 \mu \mathrm{g} / \mathrm{mL}$, fibrin degradation products (FDP) $10.06 \mu \mathrm{g} / \mathrm{mL}$ 로 상승하 였다. 더 이상의 치료에 호전이 없고 임상 상태가 악화되어 내

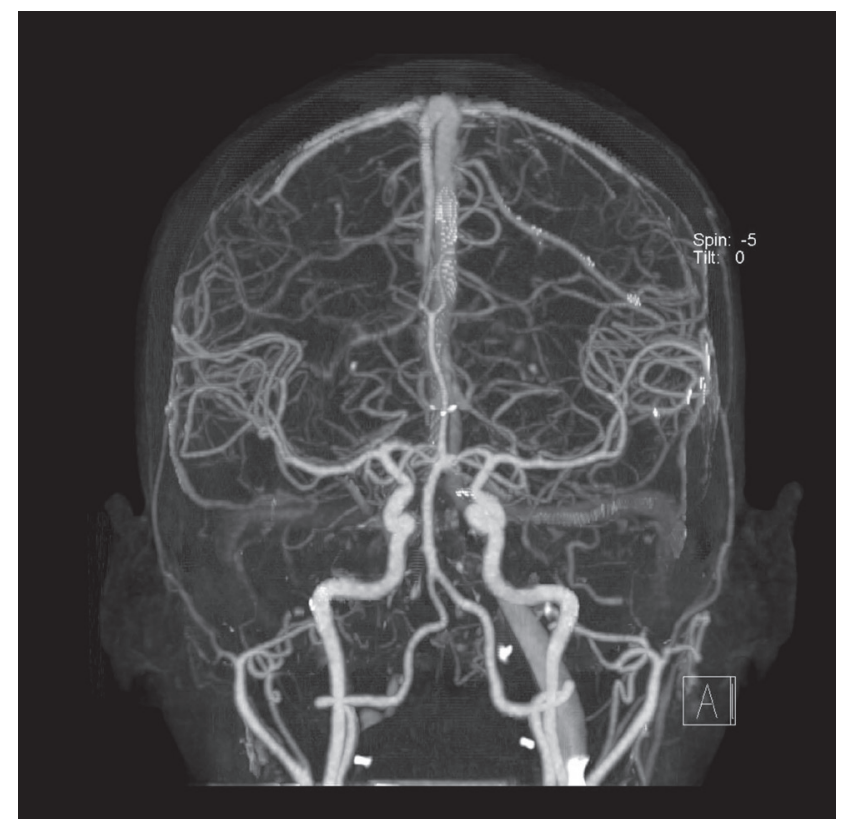

FIG. 2. Computed tomography angiography revealed no stenosis or occlusion of the intracranial arteries. 
원 9일만에 사망하였다.

\section{고 찰}

본 증례는 평균 동맥압 $50 \mathrm{mmHg}$ 를 보이는 저혈압과 혈량 저하를 가진 패혈쇼크에서 자기공명영상의 FLAIR 고강도혈관 을 보인 경우이다. 패혈쇼크에서 의식장애를 동반하는 경우에 뇌병변을 배제하기 위하여 자기공명영상을 시행할 수 있는데, FLAIR 고강도혈관은 뇌혈관의 자동조절 이상을 보여주는 영 상이다.

패혈증은 전신 저혈압, 대뇌 기능 이상, 혈압 저하로 인하 여 뇌혈류 자동조절의 이상이 올 수 있다. 뇌혈류 자동조절을 할 수 있는 평균 동맥압은 개개인에 따라 다를 수 있지만 하한 점은 50-60 mmHg 정도로 여겨진다. ${ }^{5}$ 패혈증에서 혈압 유지 의 목표는 뇌혈류 속도의 자동조절 하한점 이상의 평균 동맥압 을 유지하는 것이다. ${ }^{5}$ 패혈증이 진행함에 따라 평균 동맥압 저 하와 혈관 기능 장애로 뇌혈류 자동조절에 이상이 생길 수 있 다. 패혈증은 동맥과 모세혈관의 기능 이상으로 자동조절의 손 상과 별아교세포와 미세아교세포 기능에도 영향을 준다. ${ }^{5}$ 경 두개도플러에서 초기 패혈증에서는 평균 혈류속도와 박동지 수의 증가와 자동조절의 유지를 보이다가, 후기 패혈증에서는 평균 혈류속도의 정상화, 박동지수의 감소와 자동조절의 손상 을 보인다. ${ }^{6}$ 심한 심부전에서도 뇌혈관의 협착이나 폐쇄 없이 FLAIR 고강도혈관이 보일 수 있다. ${ }^{7}$ 본 증례에서 보인 패혈쇼 크에서의 고강도혈관은 뇌관류 저하로 인한 뇌혈류 자동조절 이상을 반영하는 소견으로 여겨진다. 본 환자는 여러 질환을 동반하고 있어 뇌혈류 자동조절이 정상인에 비하여 저하되어 있었을 것이며, 평균 동맥압도 $50 \mathrm{mmHg}$ 정도로 낮아서 고강 도혈관이 FLAIR 영상에서 보인 것 같다. 경두개도플러는 박 동지수만 증가되고 평균 혈류속도는 정상이었던 것으로 보아 초기에서 후기 패혈증으로 넘어가는 단계로 생각해 볼 수 있을 것이다.

패혈증에서의 뇌 자기공명영상은 국소적인 신경징후가 있 는 경우에 허혈성 혹은 출혈성 뇌손상을 배제하기 위하여 시행 할 수 있다. 패혈증이 조절이 되거나 주요 교란인자를 배제하 였는데도 지속적인 뇌병증이 있는 경우에 시행하여야 한다. ${ }^{8}$ 뇌 자기공명영상 소견은 급성기와 만성기로 나눌 수 있다. 급 성기는 해마와 피질의 허혈성 병변으로 세포독성부종이 나타 나며, 혈관성부종과 가역적 후뇌변성(posterior reversible leukoencephalopathy)이 생길 수 있다. 생존하는 경우에 만 성적으로 이마겉질(frontal cortex)과 해마의 뇌위축과 백질변 성을 보일 수 있다. ${ }^{8}$ 패혈쇼크의 뇌부검 소견으로는 허혈, 출 혈, 파종혈관내응고, 미세농양, 다초점괴사성 백질변성이 있으 며, 혈액뇌장벽의 장애로 인하여 주로 생기고 대사성 혹은 염 증성 매개체로 인한 신경손상으로 생긴다. ${ }^{9}$ 또한, 심한 뇌 염
증, 산화질소로 인한 신경 세포자멸사로도 생길 수 있다. ${ }^{10}$

패혈증에서 자기공명영상을 촬영하는 경우에 기존에 보고 된 이상 소견들 외에도 뇌혈관 자동조절의 손상을 반영하는 지 표로서 FLAIR 고강도혈관에 대한 관심을 가지는 것이 패혈증 과 관련된 뇌 상태를 이해하는데 도움이 되겠다.

\section{REFERENCES}

1. Sharshar T, Carlier R, Bernard F, Guidoux C, Brouland JP, Nardi O, et al. Brain lesions in septic shock: a magnetic resonance imaging study. Intensive Care Med. 2007;33:798-806.

2. Finelli PF, Uphoff DF. Magnetic resonance imaging abnormalities with septic encephalopathy. J Neurol Neurosurg Psychiatry. 2004;75:1189-1191.

3. Lee KY, Latour LL, Luby M, Hsia AW, Merino JG, Warach S. Distal hyperintense vessels on FLAIR: an MRI marker for collateral circulation in acute stroke? Neurology. 2009;72: 1134-1139.

4. Liu W, Xu G, Yue X, Wang X, Ma M, Zhang R, et al. Hyperintense vessels on FLAIR: a useful non-invasive method for assessing intracerebral collaterals. Eur J Radiol. 2011;80:786791.

5. Goodson CM, Rosenblatt K, Rivera-Lara L, Nyquist P, Hogue CW. Cerebral blood flow autoregulation in sepsis for the intensivist: why its monitoring may be the future of individualized care. J Intensive Care Med. 2018;33:63-73.

6. de Azevedo DS, Salinet ASM, de Lima Oliveira M, Teixeira MJ, Bor-Seng-Shu E, de Carvalho Nogueira R. Cerebral hemodynamics in sepsis assessed by transcranial Doppler: a systematic review and meta-analysis. J Clin Monit Comput. 2017;31:1123-1132.

7. Kim D, Lee SY, Seo KD. FLAIR hyperintense vessel sign of both MCAs with severe heart failure. Case Rep Neurol Med. 2016;2016:5169056.

8. Sonneville R, Verdonk F, Rauturier C, Klein IF, Wolff M, Annane $\mathrm{D}$, et al. Understanding brain dysfunction in sepsis. Ann Intensive Care. 2013;3:15.

9. Choi BR, Kim JS, Yang YJ, Park KM, Lee CW, Kim YH, et al. Factors associated with decreased cerebral blood flow in congestive heart failure secondary to idiopathic dilated cardiomyopathy. Am J Cardiol. 2006;97:1365-1369.

10. Sharshar T, Gray F, Poron F, Raphael JC, Gajdos P, Annane D. Multifocal necrotizing leukoencephalopathy in septic shock. Crit Care Med. 2002;30:2371-2375. 